\title{
Marriage System of Nyentana and Legal Consequences for Children Born in it
}

\author{
I Gusti Ngurah Agung Niki Diatmika ${ }^{1}$ and I Nyoman Sujana ${ }^{2}$ \\ \{agungniki@yahoo.com ${ }^{1}$ \} \\ Universitas Warmadewa, Denpasar-Bali, Indonesia
}

\begin{abstract}
This study has two objectives: (1) to reveal the legal standing for men who get married under nyentana system, marrying and following their wives and parents-in-law, toward inheritance left by their parents-in-law according to Balinese customary law. The method used in normative legal research method. The results of this study indicate that a man getting married under the system of nyentana is not entitled to inherit any inheritance before the legal decision of the Pesamuhan Agung III, the Main Assembly of Desa Pakraman issued. However, after a man is set with a status of a married man under nyentana, he is entitled to get half of the purusa inheritance rights. Then, the legal consequence for the men and children born from their marriages when being separated from their wives is the man is free from the marriage bond and child custody is the right of his wife.
\end{abstract}

Keywords: Legal consequences; marriage; nyentana

\section{Introduction}

Historically, long-term single women were more economically advantaged than their counterparts; this has changed as more married women become less dependent on their spouses, which in turn has ramifications for less economic disadvantage with marital dissolution [1]. Ecofeminism sees the global development paradigm as destroying diversity, both cultural and biological, and women as the main victims of this process by severing their bond with the land and destroying their subsistence economy [2]. International marriage migrant women are expected to become pregnant and give birth early on in their marriage [3]. Marriage unions are central in establishing and positioning a person within a society [4]. Regardless of how and why girl child marriage persists, the practice of child marriage has adverse social, economic and health consequences for girls [5]. Forced and arranged marriages are not made exclusively for economic reasons, but often to restore family honor [6]. Preferences for height and family relationships are thought to change if socioeconomic conditions change [7].

In living their lives, humans experience three important events, namely birth, marriage and death. These three events have rules in national law and local law and the three also often cause certain legal consequences. Humans as legal subjects are in real effect since the man was born until he died. However, there are exceptions for children who are still in the womb, that is, they are considered to have been born if their interest is desired [8].

The inheritance system adopted by indigenous peoples in Indonesia has three types, namely the collective inheritance system, major inheritance, individual inheritance. The collective inheritance system is when the inheritance gets the inheritance they receive 
collectively from inheritance providers who are not individually divided. The major inheritance system applies if the inheritance is not shared and only controlled by the eldest child, meaning rights of use, the right to process and collect the results is fully controlled by the eldest child with the right and obligation to take care of and care for the younger siblings until they are independent. The individual inheritance system occurs when the inheritance is divided and can be owned individually with ownership rights, which means that each heir has the right to use, rights to cultivate, and the rights to enjoy the results, as well as to transact, especially after the inheritor has died [9].

In relation to customary law, Balinese customary law adheres to a patrilineal family system, where family membership is withdrawn or taken into account based on male lineage (father). The patrilineal family system embraced by the Balinese community is a major inheritance system, which causes only descendants of deceased status, male position is more important than his sister who is considered to be able to take care and carry on family responsibilities, both in relation to Hindu beliefs, Hindus, as well as the preservation of the natural environment in accordance with the beliefs of Hindus. Based on this evidence, only male descendants have rights to inheritance. Meanwhile, men who do nyentana marriages are pradana (women), it is not possible to continue their responsibilities, so that they are equated with people who leave family responsibilities and therefore are not considered entitled to inheritance in the family.

The position of men in the traditional marriage nyentana is as pradana. In this case there is a lot of interpretation that men who engage in traditional marriages shall be like women who get married and are out of their parents' family will get their rights back. However, the phenomenon that occurs states that there are still many boys who find it difficult to obtain inheritance rights or their position again in their biological parents.

In this study, we outline the conditions of marriage that take place under the nyentana system from a legal perspective on men's rights and obligations to their parents-in-law's inheritance and to children born from their marriages when divorce occurs. The consequences arising from the divorce not only have an impact on both parties but will also affect their offspring. According to the customary law of marriage of Balinese people, which adheres to the patrilineal or purusa system, when divorce occurs all children born from the marriage will be the responsibility of their fathers and the children underage are cared for by his mother, while in marriage system of nyentana, the purusa is mother or women.

\section{Discussion}

\subsection{Legal Position on the Right to Get Parents' Heritage for Married Men under Nyentana System According to Balinese Customary Law}

The position of men in the marriage system of nyentana according to Balinese customary law, especially in obtaining rights from inheritance from the in-laws' assets is that before the decision of the Pesamuhan Agung III of Main Assembly of Desa Pakraman was issued, they could not get any rights. This is because those who belong to the inheritance recipient group are sons, daughters from sentana rajeg and men or women adopted children. If a son-in-law who is getting married under the nyentane marriage system is not classified as a child who legally has become a son-in-law who is a child of the family-in-law, heirs are the descendants of father lineage drawn up, such as uncles and offspring lineages from men to the side, like nephews. 
Through the decision of pesamuhan Agung III MUDP about the validity of the position of a man who was appointed as a son-in-law who follows the family of his wife and parents-inlaw, the rules issued are expected to provide benefits and create a sense of happiness for the man who marries the system. What is meant is that a man who is married under nyentana system, who initially does not have any rights in obtaining his parents-in-law's inheritance, can obtain clear rights in inheriting property after the decree of the Agung III MUDP decree concerning the position of men who are married to the system yell at the point. Every man who is married to the nyentana system is expected to be entitled to inherit at least half of his parents-in-law with a ratio of $2: 1$; the man in the flight system who has a prada/dying status is limited to the right to a part or half of the inheritance received by a child with kapurusa status; a boy who dies of full court is not entitled to inheritance but can be given provisions (jiwadana) by his parents from the treasure without harming the heirs.

\subsection{Customary Legal Consequences for Men and for Children Born in Nyentana Marriage when Divorce Occurs}

The result of customary law for men who are pradana in nyentana marriage is that the man returns to his biological parents' house, and if he is received well by his family, as at the time of his unmarried marriage, he will have the status of being a young man (back bachelor). Therefore, his obligations and rights as a child in the home of his biological parents will return as he is still not married. In addition, the child who has been married will automatically follow his mother's (matrilineal) lineage. However, apart from court decisions and the provisions of awig-awig of Desa Pakraman, the father also has the right to maintain and educate his son as stipulated in Article 41 paragraph a of Law No. 1 of 1974 concerning Marriage. In this paragraph it is stated that "Both mother or father always have an obligation to maintain and educate their children, solely based on the interests of children; if there are disputes concerning the control of children, the court issues its decision; "By adhering the Law number 1 in 1974 Article 41 paragraph a, the form of sexual marriage carried out by the community, especially the indigenous people of Bali, when the divorce occurred both parties are obliged to be mutually responsible for the children born in their marriage.

If analyzed according to the theory of expediency, which benefits based on happiness, an assessment of good or bad and fairness or not a law depends on whether the law provides as much happiness as possible for the community. The purusa status should be centered on children raised and educated by fathers and mothers so that children who live after divorce get complete love and happiness. All parents would expect their child to be a talented child and have a bright future. In the teachings of "Hinduism" the understanding of suputra can be described as follows: Su means good and the Son has the meaning of a child. So, suputra is a good child who can make his parents happy. Suputra is a reflection of parents who have educated their children well. Therefore, how happy are parents who have suputra children educated from their childhood properly.

Educating suputra children is not easy. Many things must be considered by the parents, including: children have not been able to distinguish good and bad behavior; the child is still in the adjustment stage. The next step is about giving enough love to children. The love that is given excessively causes the child to become spoiled. In addition, things that need to be considered by parents are the education system that is implemented in educating their children. This education system is very influential on the formation of children's personality. In this case, parents act as the main pillar. In other words, the child's life is more familycentered and the formation of his personality is largely determined by the parents. In the 
formation of a child's personality, parents apply two patterns of socialization. Both patterns of socialization are repressive socialization patterns and participatory socialization.

Repressive socialization means child obedience to parents. His trademark is that parents give punishment for their children's wrong behavior. The positive impact is that children will become more disciplined and more obedient to parents. Meanwhile, the negative impact is the child's soul will be confined because of all its activities, fully determined by parents.

Participatory socialization means socialization based on the child's willingness (participation) in determining the steps. Its trademark is the giving of reprimand to wrong behavior and the compliments on good performance. The goodness of this socialization pattern is that children can move according to their will but are still in the supervision of parents. In addition, children can develop their creativity optimally. However, this pattern also has weaknesses, namely if parents are too careless or giving excessive freedom to their children, children will become spoiled and uncontrolled. This will cause children to fall into a bad direction, and therefore, every parent is advised to implement a participatory socialization pattern. The rationale is that children are free to be creative and active but that it remains under parental supervision. This socialization pattern is synonymous with a subtle approach to educating children. Therefore, if parents are able to provide good supervision, a good child's personality will be formed optimally.

Children really need motivation in every step of living their lives. Motivation can come from friends, teachers, the community, close relatives, and parents. However, the most memorable motivation is the one presented by who love him most. Thus, motivation from the family, especially parents is a motivation that is needed by the child. By giving motivation, the child feels that he is given an award by another person. Psychologically, this award provides extraordinary abilities and strengths so that the child believes that he can achieve a hope.

Motivation is the initial capital for children to assemble their dreams in the future. In addition, with a good socialization pattern a good personality can be formed. Motivation and good personality patterns can encourage them to create a bright future. This is the sign of the door of success that will stand right in front of the child's eyes. Suputra children who are successful will bring happiness to parents and their families. That happiness will continue as time goes by.

\section{Conclusion}

The legal position for a man who marry a woman under nyentana system based on Balinese customary law is in a situation that is not entitled to get anything from his father-inlaw's property before the legal decision of the Agung III General Assembly of the Desa Pakrama. For the Balinese people, every man who has a married marriage is signed as a person who has left the family of his biological parents along with his rights and obligations as a child with a purusa status. Essentially, all sons should be a child who is obliged to continue the descent in the family of his biological parents. However, with the birth of the nymph marriage system, the boy who follows him can no longer carry out his obligations as a child and is not entitled to the family inheritance of his biological parents, in any form (dying of full court). In contrast to this fact, after the Main Assembly of Pakraman Village established through the Pesamuhan Agung III that a man married under nyentana system of marriage and is included a limited death, still carrying out swadharma as a Hindu, he is able to obtain inheritance based on the principle of Asuwun Ategen (two to one). 
Legal consequences for men and children born from traditional marriage of nyentana if a divorce occurs are men return to their biological parents' families and are not single. In addition, if divorce between men and women is divorced, the child born in his marriage automatically follows the mother's line. However, apart from the court's decision, the father also has the right to preserve and educate his child.

\section{References}

[1] Newton, N, J., Ryan, L, H., King, R, T and Smith, J.: Social Science \& Medicine Cohort differences in the marriage e health relationship for midlife women. Soc. Sci. Med. Vol. 116. pp. 64$72(2014)$

[2] Development, E, L.: Purdah , purse and patriarchy: The position of women in the Raika shepherd community in Rajasthan ( India ). pp. 1-10 (2017)

[3] Korea, S., Sun, M., Park, M and Kim, J, A.: First childbirth experience of international marriage migrant women in South Korea. Women and Birth (2017)

[4] Agha, N.: Women â€TM s Studies International Forum Kinship in rural Pakistan: Consanguineous marriages and their implications for women. Womens. Stud. Int. Forum. Vol. 54. pp. $1-10(2016)$

[5] Pandey, S.: Children and Youth Services Review Persistent nature of child marriage among women even when it is illegal: The case of Nepal. Child. Youth Serv. Rev. Vol. 73. pp. 242-247 (2017)

[6] Pastor, M., Almansa, P and Jiménez, I.: Arranged Marriages : Women For Sale. Procedia- Soc. Behav. Sci. Vol. 132. pp. 564-569 (2014)

[7] Yamamura, E and Tsutsui, Y.: Comparing the role of the height of men and women in the marriage market. Econ. Hum. Biol (2017)

[8] Soeroso, R.: Pengantar Ilmu Hukum. Jakarta: Sinar Grafika (1996)

[9] Hadikusuma, H.: Pengantar Ilmu Hukum Adat Indonesia. Bandung: Mandar Maju (2003)

\section{Legislation}

Keputusan Pesamuhan Agung III Majelis Utama Desa Pakraman Bali Nomor 01/Kep/Psm-3/MDP Bali/X/2010 tanggal 15 Oktober 2010. 